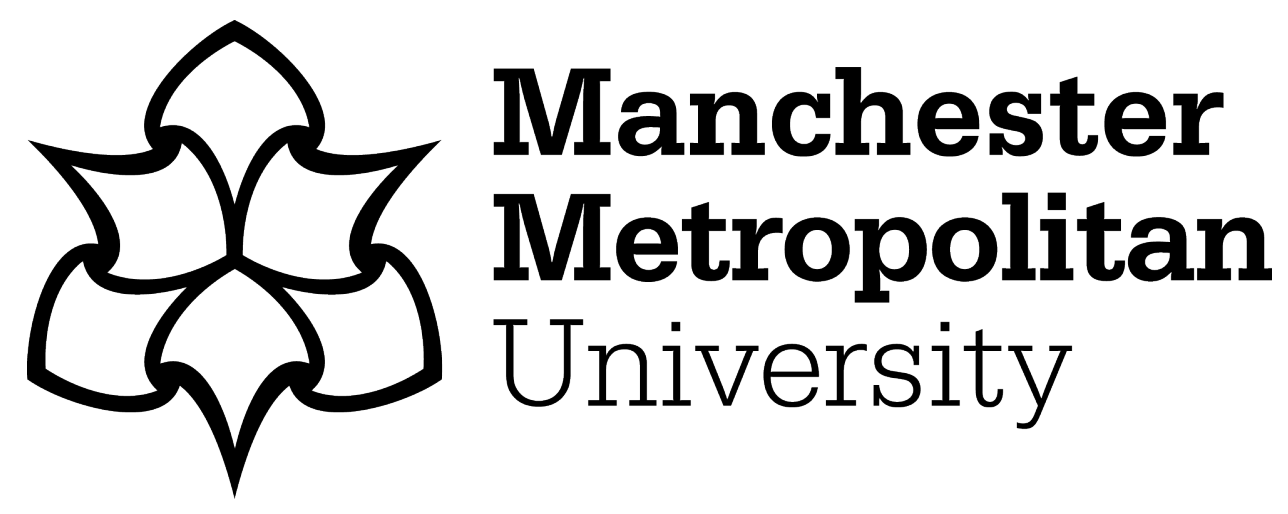

Dennis, Joanna (2017) Imagining powerful co-operative schools: Theorising dynamic co-operation with Spinoza. Educational Philosophy and Theory, 50 (9). pp. 849-857. ISSN 0013-1857

Downloaded from: https://e-space.mmu.ac.uk/619273/

Version: Accepted Version

Publisher: Taylor \& Francis (Routledge)

DOI: https://doi.org/10.1080/00131857.2017.1382350

Please cite the published version 


\section{Imagining powerful co-operative schools: Theorising dynamic co-operation with Spinoza}

\section{JOANNA DENNIS}

Education and Social Research Institute, Faculty of Education, Manchester Metropolitan University,

Brooks Building, 53 Bonsall Street, Manchester, MI5 6GX.

j.dennis@mmu.ac.uk

joannalouisedennis@gmail.com

This is an Author Accepted Manuscript of an article published by Taylor and Francis Group in Educational Philosophy and Theory on 05/10/2017, available online:

http://www.tandfonline.com/I0.1080/00 I 3 I857.2017.1382350

To cite this article: Joanna Dennis (2017): Imagining powerful co-operative schools: Theorising dynamic co-operation with Spinoza, Educational Philosophy and Theory, DOI: 10.1080/00131857.2017.1382350 


\begin{abstract}
The recent expansion of the English academies programme has initiated a period of significant change within the state education system. As established administration has been disrupted, new providers from business and philanthropy have entered the sector with a range of approaches to transform schools. This paper examines the development of cooperative schools, which are positioned as an 'ethical alternative' within the system and have proved popular with teachers and parents. Using a theory of co-operative power drawn from the philosophy of Spinoza (1632-1677), the author explores how co-operative schools have emerged, with and against the reforming agenda, using narratives of hope and resistance. Spinoza provides theoretical resources to critique this positioning and to project beyond the limiting narratives to an affirmative vision for co-operative schools.
\end{abstract}

Key words: academies; academisation; co-operative schools; Spinoza.

'Spinoza did not believe in hope or even in courage; he believed only in joy and vision'

(Deleuze, 1988, p. 14)

In May 2010 a new UK government entered parliament with a radical plan to transform England's schools. The proposals were ambitious and divisive, envisaging profound change to local governance structures and an increased role for business and philanthropy (DfE, 20I0). The key mechanism for these reforms was to be an increase in the number of academy schools, a type of centrally funded 'independent state school' (p. 5I) operating outside of local authority control. The ensuing Academies Act (2010) provoked a 'new education landscape' (Gilbert, Husbands, Wigdortz, \& Francis, 20/3) by expanding the existing academies programme and extending the powers of central government in education. Schools have been incentivised and coerced to adopt academy status (Ball, 20I6) and the systemic transformation has been profound (Finn, 20I5). In the midst of this disruption, and in response to changing threats and opportunities, the co-operative movement has developed a range of school models that have appealed to teachers and parents. There are currently $600^{\prime}$ co-operative schools, which are positioned as ethical, values-based alternatives (Facer, Thorpe, \& Shaw, 20I2) to standard corporate and competitive academy models (Keddie, 20I5).

The growth of co-operative schools has been met with enthusiasm from academics who see the transformative potential of co-operative and democratic education (Woodin, 20 II, 20I5a; 20I5b; Woodin \& Fielding, 20I3; Coates, 20I5; Mills, 20I5; Woods, 20I5). This paper, which reports on a qualitative case-study of the emerging movement, contributes to

\footnotetext{
${ }^{1}$ Figures provided by the Co-operative College, UK in April 2017.
} 
the literature by attending to the motivations and expectations of those involved. I begin by describing the co-operative schools movement and outlining the policy context that has created the conditions for its growth. Then I explain the connection that I make between these schools and Spinoza's philosophy, going on to trace the concept of 'co-operative power' that I find the Ethics ${ }^{2}$. In the final section, I analyse the emerging movement and identify prevalent narratives of resistance and hope, which Spinoza interprets as 'sad passions'. I argue that such passive articulations serve to undermine co-operative power. I conclude that Spinoza's dynamic theory of co-operation offers an affirmative rationale for co-operative practice.

\section{Academisation and the growth of co-operative schools}

Drawing on a historic and 'symbiotic' relationship with state education (Vernon, 2013:3), the co-operative movement has used recent changes in legislation (Ball, 2007; Exley and Ball, $2014)$ to enter the sector with a range of co-operative schools. ${ }^{3}$ These models claim an 'ethical character', the fundamental basis of which is drawn from globally agreed cooperative values of self-help, self-responsibility, democracy, equality, equity and solidarity (MacPherson, 1995).

The first co-operative trust school opened in 2008 and a small network developed over the next couple of years, with numbers dramatically increasing following the expansion of the academies programme from 2010. Initially, Co-operative College positioned the trust schools as an alternative to academisation and, with changes to legislation, the co-operative convertor academy was developed as an alternative within the academies programme. In both cases, academisation was a significant factor in the number of schools that approached the Co-operative College looking for an alternative.

The academies programme is understood as part of a global education reform movement (Ball, 2012), which conceptualises school improvement through the logic of the marketplace and the power of competition (Exley \& Ball, 20I4). Introduced in 2000, as a radical solution for underperforming secondary schools in urban areas, the first academies were independent of local authority administration and sponsored by business (West and Bailey,

\footnotetext{
${ }^{2}$ Conventional abbreviated citation is used when referring to Spinoza's Ethics (e.g. EIP8S2 refers to Ethics, Part I Proposition 8, Scholium 2). Citations for the Ethics are quoted from Spinoza, B. (1996) Ethics, Edwin, M. Curley (trans.), London: Penguin 1996.

${ }^{3}$ There are three co-operative models, which were developed with investment from the Co-operative Group, UK and the Co-operative College, UK. These are: co-operative 'trust' schools, co-operative 'sponsored' academies and co-operative 'convertor' academies (for a full account see Woodin, 2015b).
} 
20I3). Although this was a high profile policy, with many critics (Ball, 2009; Gorard, 2009), it was relatively small-scale and just 203 academies were operating by 2010 .

The expansion of the programme from 2010 has initiated a huge increase in numbers. As of June 2017 the number of academies stands at 6398 (DfE, 2017). The new legislation makes provision for all schools to become academies and grants additional powers to the Secretary of State, including the power to recommend that a poor performing school should become a sponsored academy. An incentivised 'convertor' model has been introduced, for 'good' and 'outstanding' schools to convert without sponsorship (DfE, 20I0). The expanded programme is highly contested (Gunter, 20I2) with particular criticism focused upon 'forced academisation' (Ball, 2016), the changing role of the public sector (Simkins, 20I5), the creation of a democratic deficit (Hatcher, 20I2) and perceived threats to social justice (Lupton, 20II).

Co-operative schools promise to overcome the issues inherent in standard academy models with an ambition to position inclusive, socially just education at the heart of local communities (Facer et al., 20I2). As we consider the stated values of co-operative schools we can begin to see how they represent the kind of education that might be adequate to Spinoza's philosophy. With their explicit claim to the ideals of self-responsibility and selfhelp, for instance, there is a sense that these schools affirm a strong measure of immanent power; and with their claim to the ideals of democracy, equality, equity and solidarity, they seem well poised to embody the Spinozist idea of the collective individual. It is to the further development of these connections that we now turn.

\section{Why Spinoza?}

The co-operative schools movement is a project of transformation (Shaw, 20I5). By positioning itself as ideologically opposed to the dominant logic of competition, and in proposing a co-operative alternative, this group of schools seeks to change current conditions within education. However, it is not immediately clear why co-operation is a good idea or how the ethics and values work to achieve the ambitions of the movement. I propose that Spinoza offers us resources with which to think through these questions. My research draws on a concept of co-operative power that I find in the Ethics and I argue that it provides an important theoretical framework with which to explore the transformative power of co-operative education. 
Spinoza is writing in $17^{\text {th }}$ century Amsterdam, during a period of significant economic change, social upheaval and political unrest (Isreal, 200I). In turning to Spinoza, we are engaging with a philosopher who thinks beyond the dominant beliefs of his time and seeks to illuminate a different possibility for social and political order. Urging his readers to see that the universe is not as it seems, he argues that there is no transcendental God, that the universe has no teleological purpose and that human individuals are just part of a complex mesh of interrelated matter. These radical revelations have a liberating capacity in Spinoza's project. He wants his readers to understand themselves as social creatures who, capable of reason and subject to emotion, have an immense capacity to form relationships and alliances with others, to create harmonious ways of life. By appealing to both reason and imagination, he offers a persuasive logical argument and a pragmatic analysis of everyday practice. He wants to inspire his readers to recognise their power and to create co-operative ways of living together (James, 2010).

Spinoza offers a distinctive means for theorising the potential of co-operative schools. In the Ethics, he presents a philosophical system that places a high value on co-operation, and he develops a novel concept of co-operative power, which is based on relation and interaction between individuals. He observes that when individuals, with a shared interest, combine to seek common goods their power is increased, so that seeking what is good for oneself means seeking what is good for others. The idea of the individual is central to Spinoza's theory of co-operation and he proposes a dynamic, mutable individuality that, through networks of alliance and relation, gives rise to increased collective power. Balibar (1997) calls this transindividuality, a reciprocal and relational individuation. For Spinoza, everything in nature is connected, there is no external cause and all parts of nature actively express the immanent power of being (Deleuze, 1990). In such a universe, individualism and collectivity are not opposites, rather the flourishing of the individual is grounded in its connections to, and with, others.

Due to limitations of space this paper will not provide a complete account of Spinoza's theory of co-operative power. In what follows I outline some useful elements of the theory, using these to illuminate research findings, and signalling how the co-operative schools might better understand themselves always as 'a community to come' (Stolze, 2015:163). 


\section{Spinoza: towards a theory of co-operation?}

Spinoza's radical universe - united, immanent and active

Spinoza's project is concerned with political power (Balibar, 1998). He explores how power is formed, how it ebbs and flows through causal relations, expressing itself in a complex network of active and passive interactions. Ultimately, he seeks to demonstrate how the human power to act is grounded in the dynamism of the universe, and increases through active co-operation with others. However, before he can make these claims, he must cast aside prevailing beliefs about the nature of the universe, of God, of transcendence and causality (Curley, 1988). In the earliest phase of his argument, Spinoza reveals the ontological foundations of his philosophy, '[e]xcept God, no substance can be or be conceived' (EIPI4) ${ }^{4}$. This is Spinoza's 'radical monism' (Williams, 2007), the claim that all being is one, there is only one being, and that being is God. In a direct challenge to Cartesian dualism, Spinoza argues that there is only one substance, 'God, or Nature' (Deus sive Natura). Spinoza's project rests upon this foundation, which places unity rather than dualism at the centre.

Spinoza's next move is to abandon the idea of transcendent power. He writes, 'God is the immanent, not the transitive, cause of all things' (EIPI8), denying the transcendental power of God as 'creator' and positioning an immanent power of actualisation, which is both the cause and effect of itself. Through this argument, we witness the 'fall of metaphysical hierarchy' (Sharp \& Smith, 2012, p.I). Transcendence becomes impossible, and power becomes intrinsic (Montag, 1999). Spinoza's doctrine of immanent causality becomes the theory of power in the universe - the active, creative power of cause, and the corresponding passivity of effect. These ideas of activity and passivity, of cause and effect are the dynamic rhythms of power at work in Spinoza's universe.

Conatus as the striving co-operative power to act

Spinoza gives an account of how immanent power is expressed through the conatus ${ }^{5}$ of every being. The conatus is the striving (Curley, 1988), which each individual undertakes to increase its power and persist in being. It is the way in which an individual responds and adapts, as cause and effect, through the rhythms of activity and passivity in the universe. This process of self-preservation can be understood as a 'strategy' of action (Bove, 1996), through which an individual conatus defends against encounters that might diminish its

\footnotetext{
${ }^{5}$ Initially coined by the Stoics (Wolfson, 1934 via Lloyd), and present in the work of Spinoza's contemporaries Descartes, Hobbes (Curley, 1988) and Leibniz (Deleuze, 1990)
} 
power, and seeks associations that will augment it. This process hints at the co-operative nature of Spinoza's conatus. In order to increase its power of acting the conatus engages in multiple relationships, seeking out useful resources with which to mix and mingle, integrate and exchange.

Spinoza tells us that conatus, is 'the very essence of man' (EIIIP9S). He explains that this essential striving is a 'will' to persevere; it manifests unconsciously as 'appetite' and consciously as 'desire' (EIIIP9S). As the unconscious appetites and conscious desires flow through the conatus it becomes a site of both imagination and reason. This link between imagination and reason is a significant move in Spinoza's ethical project, by understanding the self-preservation of the conatus as a rational endeavour it becomes a virtuous process (Lloyd, 1996). Spinoza understands reason and virtue as the same thing and writes, "it is clear that we neither strive for nor will, neither want, nor desire because we judge it to be good; on the contrary, we judge something to be good because we strive for it, will it, want it, and desire it' (EIIIP9S). The striving to persevere is the vital thing and, at once, it becomes both the reason and the purpose. The good in itself. Spinoza writes, 'the foundation of virtue is this very striving to preserve one's own being, and [that] happiness consists in a man's being able to preserve his being' (EIVPI8S). Thus, there is no conflict between selfseeking and altruism because self-preservation is the good in itself, the foundation of virtue, and the way to harmonious living (Lloyd, 1996). In a clear depiction of conatus as a cooperative power Spinoza explains how we must look 'outside ourselves to preserve our being' (EIVPI8S). He describes how, in joining with others, we increase our power to act:

'[For] if, for example, two individuals of entirely the same nature are joined to one another, they compose an individual twice as powerful as each one. To man, then, there is nothing more powerful than man. Man, I say, can wish for nothing more helpful to the preservation of his being than that all should so agree in all things that the minds and bodies of all would compose, as it were one mind and one body; that all should strive together, as far as they can, to preserve their being; and that all, together, should seek for themselves the common advantage of all' (EIVPI8S)

Whilst the conatus is 'individual self-maintenance' (Hampshire, 1951:78) it is also the way in which the particular participates in the universal, so that "by preserving oneself one contributes to the preservation of the entire universe of which we are all an infinitesimal part' (Mack, 2010:8). 


\section{Mind as the idea of the body - the role of affect and imagination}

In order to propel itself through life the conatus draws upon and maximises all available resources, including those of body and mind. Spinoza attends to the way in which the power of the conatus flows through body and mind as both passion and emotion, imagination and reason. For Spinoza, mind and body are not separate substances, nor is the body and its passionate affects inferior to the mind and its rational processes. On the contrary, Spinoza contends that the mind and body are intrinsically related expressions of the same human individual, he explains that 'the idea of any thing that increases or diminishes, aids or restrains, our body's power of acting, increases or diminishes, aids or restrains, our mind's power of thinking' (EIIIPI I). To give a full account of the dynamic power of the conatus, Spinoza's analysis explores the way in which reason and imagination come together in the human body and mind as active and passive forces.

Spinoza tells us that the imagination is a passive realm in which individuals are occupied by inadequate ideas and subject to multiple affects, and that the rational mind is an active realm in which individuals are in possession of adequate knowledge and have freedom from the passions (Balibar, 1997). The point is not to give primacy to either one of these realms but to understand the continual play of activity and passivity that persists within every moment. As the striving conatus negotiates this terrain, both within itself and along with others, it encounters a range of ideas and affects that serve to increase and diminish its power to act. This theory offers an analysis of human affects and an explanation of how these work to empower and disempower the striving conatus. Spinoza observes that as the conatus engages in multiple affective encounters, such as love and hate or hope and fear it operates with greater and lesser consciousness, and increases or diminishes its capacity for joy and sadness. For Spinoza, joy is the 'passage from a lesser to a greater perfection' (ElIIDefAff) and sadness is its opposite. As our conscious power of acting is increased we experience greater joy, as our conscious power of acting is decreased we experience greater sadness. Thus there is a connection between the striving power of the conatus and the passions, which directly relate to the conative power to act. As we consider the emerging power of the co-operative academy it is pertinent to attend to the affective passage of the school as it assumes its new status. It is with an idea of the conatus of the transforming school ${ }^{6}$ that I now track the accounts of this process of change by those directly involved.

\footnotetext{
${ }^{6}$ In the analysis that follows I position the co-operative academy school as an individual in the ontological sense. That is, as a complex 'body politic' (Balibar, 1998:64) an 'individual of individuals' (p.64). Balibar's interpretation of
} 


\section{An affective analysis of school conversion to co-operative status}

This study examines the emergence of the co-operative 'convertor' academy. These are 'good' or 'outstanding' schools, which have academised and assumed a co-operative status. Qualitative research was conducted between 2014-2016 and sites of fieldwork included the Co-operative College and four co-operative academy schools. Research was undertaken at a time of upheaval, following a notable growth period and when these schools were in the earliest phase of their new identity.

This section focuses upon the motivation of schools to adopt co-operative status, identifying three significant perceptions, which emerged as motivating factors during the research. Firstly, that the co-operative ethos represented a hopeful possibility, secondly that it would involve minimal change to existing ethos, and thirdly that it served to ameliorate concerns about academisation. Most participants suggested that the decision had been informed by a combination of these factors, which I have interpreted as manifestations of resistance and hope, sparked by the contentious education reforms and positioned as galvanising narratives within the co-operative schools movement. Spinoza's concept of co-operative power allows us to critically examine these positions and to trace the emerging co-operative academy as it strives to persist and increase its power to act.

Research began at the Co-operative College in 20I4, where I spoke to those who had played a significant role in developing the co-operative schools. The previous years had been busy and the atmosphere at the College was buoyant. The CEO spoke with delight at way in which the education sector had been inspired by co-operation. He believed that the cooperative schools movement had returned a sense of hope, offering itself as a form of resistance and alternative to a fully privatised system. It was evident that the growth of the movement was a response to academisation. Reflecting on this, the CEO made a link to the political context and the ideological drive of academisation,

'First of all, is the context of this, which has been the lifetime of the [Coalition] administration and is just coming to an end. An overwhelming political desire to break up the old system, with all the eggs in the single basket of academisation' (CEO, Co-operative College, 2015).

Spinoza's theory of individuation is discussed by Gatens and Lloyd (1999, ch. 5). For an argument that runs counter to this see Rice (2011). 
He acknowledged the systemic change and reflected upon how this had motivated some schools,

'The status quo is not an option. That change is there. Certainly, there is an element of 'the least worst option' for some, as oppose to a positive choice of wanting to do things' (CEO, Co-operative College, 20I5)

In recognising that some schools had undertaken a passive course of 'the least worst option' rather than make a 'positive choice' of co-operative action he reveals a significant weakness in co-operative motivation. The CEO did not directly address this question, however other members of the team expressed unease about the process,

'Conversions happened without ever really establishing the school's motivation for becoming a co-operative school - what were they doing it for? Were they doing it to become a co-operative school, or for some other reason?' (Staff member, Co-operative College)

Evidence suggests that motivation was not adequately addressed as schools converted. A staff member told me that the strategy had been, 'sign them up, get them converted and then grow co-operation in the months and years that followed'. I argue that this lack of concern for motivation, combined with an absence of strategy, is likely to have had a deleterious effect on co-operative power. As Spinoza demonstrates, an ethic of cooperation emerges when the collective individual has an active relationship towards the mutable universe. The immanent power of being situates causality in the world of our own actions. Schools must actively engage with their transformation in order to increase their power of acting. Furthermore, whilst it is possible to understand the spirit of optimism that drove the course the growth, it is disappointing to note that there was no strategy and limited resources to undertake post-conversion work. This was presented as a strength of the movement, suggesting that since there was 'no blueprint' schools were empowered to define their co-operative nature. In practice this meant that schools, which had not fully interrogated their reasons for conversion, were then invited to interpret their new status on their own, with varying degrees of success, ironically affirming the kind of individualism that runs counter to the stated co-operative ideals. That the process of 'becoming cooperative' should be left entirely to the schools themselves calls into question the idea that co-operation is indeed co-operative and, I argue that the lack of strategy also positions 'hope' as the main force of change. 
As the field of study expanded to include the schools, I began to get a picture of the upheaval that the sector had endured. There was a sense in which the schools felt that they had been 'striving' for their survival and attitudes towards the academies programme were described in affective terms. One head teacher recounted her 'dismay', another described parents as 'up in arms', and another explained that governors were 'highly resistant'. As research progressed, it became apparent that the co-operative academy had been seen as a way of resisting or diverting elements of the unpopular agenda.

There were those saw the co-operative academy as a way of retaining the character of their school. These leaders felt that the co-operative values were a close approximation of their existing school ethos so that the co-operative academy seemed to offer minimum change. The CEO suggested that these schools were 'changing to stay the same', and my analysis points to a potential compromise of co-operative power. The following quotation from a parent governor describes how the co-operative academy was presented,

'To all intents and purposes I don't think that most people would have a clue that there has been any change at all ... it was a way forward that meant that they could be an academy but still be how they were ... The message was that we won't be the same as the other group academies that you have heard about, we are not going to become a business, we are going to carry on doing the right thing and being a co-operative was a way of doing that' (Parent Governor, Raines Chase Community College).

The message that the school was going 'carry on doing the right thing' that they would 'be an academy but still be how they were' suggests that this school sought to preserve itself by adopting the co-operative model. Using Spinoza's concept of the conatus, we can see how this is a form 'static self-preservation' (Matheron via Duffy, 2010). The conatus is not simply a preservation of one's current capacities but also always entails a dynamic relationship to the future and a determination to increase one's power to act through collective relations. Therefore a static approach is likely to weaken the power to act. A dynamic co-operative academy would always act for transformation not preservation, and would be less concerned with assuming a 'co-operative identity' than with pursuing co-operative power to act.

Some school leaders saw the co-operative model as a way of overcoming resistance to academisation. They felt that the co-operative model served to ameliorate the concerns of those strongly opposed to academisation. One leader explained this, 
'It appealed to a group of my governors who, idealogically, are opposed to what this government is doing to education. By that I mean diversifying and quasi-privatising it, separating schools from each other and from the Local Authority. So they are fundamentally, idealogically opposed to that and felt that the co-op with its roots in local democracy offered a strong alternative - an alternative based in the values that they believed in' (Principal, Woodby School).

This school leader felt that the co-operative model 'softened the blow' of academisation by allowing these schools to make transition with the support of all stakeholders. One leader described the co-operative model as, 'a compromise to get the school into that new place'. There was an attitude of fear towards acdemisation and the co-operative model was interpreted as a hopeful alternative. Spinoza's idea of sad passions reveals how this positioning compromises the conatus. Spinoza suggests that 'hope is an inconstant joy' (ElIIDefAff), which arises from an idea of a future or past thing the outcome of which is in doubt and that 'fear is an inconstant sadness' (EIIIDefAff), which arises from an idea of a future or past thing the outcome of which is in doubt. So using this analysis both hope and resistance become non-affirmative states. In contrast, Spinoza tells us that 'confidence is a joy born of the idea of a future or past thing concerning which the cause of doubting has been removed' (EIIIDefAff). Thus, hope and resistance are non-affirmative states, while confidence and a strategy of action to augment power are the means of affirmation. This analysis shows how sad passions are entailed in the reasoning about school conversion with a diminishing effect on the conatus. Whilst the co-operative academy is positioned as a hopeful alternative it is always already a diminishing possibility and a cause of sadness, the hopeful are called to imagine a future where their ideal school is possible but the very nature of hope means that they are always in doubt, fearing that its impossibility will be the certain outcome.

I suggest that the absence of a strategy for the growth and development of the co-operative academy schools has diminished their power to act, and reduced their future-oriented state of confidence. Beyond the stated ideals of cooperation, there is no consideration given to how schools might become co-operative and what it would mean for them to be so. A set of ideals is static, but a set of practices is dynamic and responsive. When the Co-operative College say that 'there is no blueprint', they fail to see how their idealism is standing in, and thus displacing, the complex relational dimension of ethical practice. I argue that the lack of concern about school motivation, insufficient resources and an absence of strategy for the 
co-operative schools movement amounts to a lack confidence in the possibility, surfacing as doubt and consigning it always to a position of hope and fortune.

The co-operative academy school was sparked from a moment of opportunity seized by the co-operative movement and embraced by professionals and parents who have faith in the co-operative values and fear their opposite. Fear and faith are insufficiently affirmative affects upon which to build a school. Narratives of hope and resistance have served to compromise the idea of the co-operative academy school and, if it is to fulfil its promise, it must redefine itself according to stronger narratives of confidence and power.

\section{Conclusion}

My research reveals that in the expansion of the co-operative schools movement there has been an insufficient emphasis on the development of co-operative ethos and practice. Whilst this is somewhat inevitable during periods of change it is now important for these schools to attend to their co-operative power. The co-operative academy tends to understand itself in terms of what it is not - it is not competitive, or not corporate, or not predatory. Despite a convincing vision the data points to a mixture of complex affects around the application of the co-operative values within the academy school, including disappointment, confusion, denial, fear and hope.

Spinoza's co-operation is active and mutable - there are many possibilities for the cooperative individual to pursue, always involving change and adaptation. There is no possibility of 'staying the same'. For Spinoza the process of co-operation is continual - it cannot be a status that you achieve nor a set of rules that you live by. It follows, therefore, that 'co-operative ethics and values' cannot be handed down from the past - for cooperation to be powerful it must be actively and continually constituted. Co-operation cannot be reduced to an 'ethical alternative' and the co-operative academy cannot be the 'acceptable face' of academisation - such positions of resistance and hope deprive it of its power to act. A successful co-operative conatus cannot be passive, static, resistant, hopeful or fearful - these are sad passions.

Spinoza gives us an account of co-operative power that reveals the potential of the cooperative academy school to take a stance of 'dynamic co-operation', which repositions the public as active stakeholders, prioritises inclusion and embraces co-operation as an affirmative operating philosophy. Of course, this has always been the vision, however the research shows a mixed picture in which cooperation is largely constrained by passive affects and static ideals. The dominance of passive passages - towards hope or resistance - 
mark the schools as diminished bodies with diminished power, and the appeal to static idealism runs contrary to Spinoza's responsive ethics. In order to enhance their power, and better animate the co-operative intentions, I argue for a more dynamic understanding of cooperation. Thinking with Spinoza, my proposal is for a co-operative school that invests in the process of 'dynamic co-operation' so as to equip itself with the power to respond to the challenges of the contemporary moment. 


\section{References}

Balibar, E. (1997). Spinoza: from individuality to transindividuality (Vol. 7I). Delft: Eburon. Balibar, E. ( 1 998). Spinoza and Politics. (P. Snowdon, Trans.) (3rd ed.). London: Verso.

Ball, S. J. (2007). Education Plc: Understanding Private Sector Participation in Public Sector Education. London: Routledge.

Ball, S. J. (2009). Academies in context: Politics, business and philanthropy and heterarchical governance. Management in Education, 23(3), 100-103. https://doi.org/I0.1 I77/0892020609/0580I

Ball, S. J. (20 I 2). Global Education Inc: New Policy Networks and the Neo-liberal Imaginary. London: Routledge.

Ball, S. J. (20 I6). Education, Justice and Democracy: The Struggle over Ignorance and Opportunity. In A. Montgomery \& I. Kehoe (Eds.), Reimagining the Purpose of Schools and Educational Organisations: Developing Critical Thinking, Agency, Beliefs in Schools and Educational Organisations (pp. 189-205). Cham: Springer International Publishing. http://dx.doi.org// 0.1007/978-3-3 I9-24699-4_I4

Bove, L. (1996). La stratégie du conatus: affirmation et résistance chez Spinoza [The Stratgey of conatus: affirmation and resistance in Spinoza] Paris:Vrin.

Coates, M. (20I5). The Co-operative: Good with schools? Management in Education, 29(I), I4-19. https://doi.org//0.I I77/08920206/4560839

Curley, E. M. (1988). Behind the geometrical method: a reading of Spinoza's Ethics. Guildford: Princeton University Press.

Deleuze, G. ( 1 988). Spinoza: Practical Philosophy. (R. Hurley, Trans.). City Lights Books, San Francisco.

Deleuze, G. (1990). Expressionism in Philosophy: Spinoza. (M. Joughin, Trans.). New York: Zone Books.

DfE. (2010). The Importance of Teaching: The Schools White Paper 2010. Retrieved from http://www.education.gov.uk/schools/toolsandinitiatives/schoolswhitepaper/b0068570/theimportance-of-teaching

DfE. (20I7). Open academies and academy projects in development: June 20I7. Retrieved from https:/www.gov.uk/government/publications/open-academies-and-academy-projectsin-development

Duffy, S. (2010). French and Italian Spinozism. In R. Braidotti (Ed.), After

Poststructuralism: transitions and transformations (Vol. 7, pp. 149-168). Durham: Acumen

Exley, S., \& Ball, S. J. (20I4). Neo-liberalism and English Education. In D. Turner \& H.

Yolcu (Eds.), Neo-liberal education reforms: a critical analysis. New York/London:

Routledge. pp. 9-49

Facer, K., Thorpe, J., \& Shaw, L. (20 I 2). Co-operative Education and Schools: An Old Idea for New Times? Power and Education, 4(3), 327-34I.

https://doi.org/I0.2304/power.2012.4.3.327

Finn, M (20 I5). The Gove Legacy: Education in Britain after the Coalition. Basingstoke:

Palgrave Macmillan.

Gatens, M. and Lloyd, G. (1999). Collective imaginings: Spinoza, past and present.

London: Routledge.

Gorard, S. (2009). What are Academies the answer to? Journal of Education Policy, 24(I), I0I-I I3. https://doi.org/I0.1080/02680930802660903

Gilbert, C., Husbands, C., Wigdortz, B., \& Francis, B. (20 I 3). Unleashing Greatness: Getting the best from an academised system. RSA Academies Commission. Retrieved from https://www.thersa.org/globalassets/pdfs/reports/unleashing-greatness.pdf

Gunter, H. M. (ed.) (20I2). The State and Education Policy: The Academies Programme. London: Continuum. 
Hampshire, S. (195I). Spinoza. England: Penguin Books.

Hatcher, R. (20I2). Democracy and governance in the local school system. Journal of Educational Administration and History, 44(I), 21-42.

https://doi.org/I0.1080/00220620.201 I.634496

Isreal, J. (200I). Radical Enlightenment: Philosophy and the Making of Modernity I6501750. Oxford University Press.

James, S. (2010). 'Narrative as the Means to Freedom: Spinoza on the Uses of Imagination.' Spinoza's Theological-Political Treatise: A Critical Guide pp. 250-267.

Cambridge: Cambridge University Press

Keddie, A. (2015). New modalities of state power: neoliberal responsibilisation and the work of academy chains. International Journal of Inclusive Education, I9(I I), I I 90-1205. https://doi.org/I0.1080/I3603 | | 6.2015.1044205

Lloyd, G. ( 1996). Spinoza and The Ethics. UK: Routledge.

Lupton, R. (20I I). 'No change there then!': The onward march of school markets and competition. Journal of Educational Administration and History, 43(4), 309-323.

https://doi.org/10.1080/00220620.201 I.606894

Mack, M. (20 I 0). Spinoza and the Spectres of Modernity: The Hidden Enlightenment of Diversity from Spinoza to Freud. New York/London: Continuum International.

MacPherson, I. (1995). Co-operative Principles for the 2 I st Century. International Cooperative Alliance, 26-29. Studies and Reports. Geneva: International Co-operative Alliance.

Mills, M. (20I5). The tyranny of no alternative: co-operating in a competitive marketplace. International Journal of Inclusive Education, 19(II), I I72-1 I89.

https://doi.org/10.1080/13603 I 16.2015.1044204

Montag, W. (1999). Bodies, Masses, Power: Spinoza and His Contemporaries. London ; New York: Verso Books.

Rice, L. C. (1990). Individual and Community in Spinoza's Social Psychology. In E. Curley \& P-F. Moreau (Eds.), Spinoza. Issues and Directions, Proceedings of the Chicago Spinoa Conference (Pp. 27I-285).

Sharp, H., \& Smith, J. E. (Eds.). (20 I 2). Between Hegel and Spinoza. London/NewYork: Bloomsbury Academic.

Shaw, L. (2015). A turning point? Mapping co-operative education in the UK. In T. Woodin (Ed.), Co-operation, Learning and Co-operative Values (pp. I6I-176). London: Routledge.

Simkins, T. (20 I5). School restructuring in England New school configurations and new challenges. Management in Education, 29(I), 4-8. https://doi.org// 0.I I77/08920206 I4559235

Spinoza, B. ( 1 996). Ethics. (E. Curley, Trans.) (2nd edition). London: Penguin Classics.

Stolze, T. (20 I5). 'Revisiting a Marxist Encounter with Spinoza: Alexandre Matheron on Militant Reason and Intellectual Love of God. Crisis and Critique: Politics and Theology Today, 2(I). Pp. I53-169.

Vernon, K. (2013). Co-operative Education and the State, c. 1895-1935. FORUM, 55(2), 293-308.

West, A., \& Bailey, E. (20 I3). The Development of the Academies Programme: 'Privatising' School-Based Education in England 1986-2013. British Journal of Educational Studies, 6I (2), I37-I59. https://doi.org/I0.1080/0007I005.2013.789480

Williams, C. (2007). Thinking the Political in the Wake of Spinoza: Power, Affect and Imagination in the Ethics. Contemporary Political Theory, 6(3), 349-369.

https://doi.org// 0.1057/palgrave.cpt.9300298

Woodin, T. (20I I). Co-operative education in Britain during the nineteenth and early twentieth centuries: context, identity and learning. In A. Webster, L. Shaw, \& J. K. Walton (Eds.), The Hidden Alternative (pp. 78-95). Manchester: Manchester University Press. 
Woodin, T. (2015a). An introduction to co-operative education in the past and in the present. In T. Woodin (Ed.), Co-operation, Learning and Co-operative Values:

Contemporary issues in education (pp. 1-16). London: Routledge.

Woodin, T. (20 I 5b). Co-operative schools: putting values into practice. In T. Woodin (Ed.), Co-operation, Learning and Co-operative Values: Contemporary issues in education (pp. I I2-127). London: Routledge.

Woodin, T., \& Fielding, M. (2013). Co-operative Education for a New Age? Forum, 55(2), 179-184.

Woods. (20 I 5). Co-operation as an alternative: choice, assimilation and challenge. In T. Woodin (Ed.), Co-operation, Learning and Co-operative Values: Contemporary issues in education (pp. 42-54). London: Routledge. 